\title{
CONTEMPORARY VIEWS ON PERSONAL IDENTITY FORMATION
}

DOMINIKA KARAŚ *

EWA TOPOLEWSKA-SIEDZIK

Cardinal Stefan Wyszyński University in Warsaw, Poland

OANA NEGRU-SUBTIRICA

Babeş-Bolyai University, Cluj-Napoca, Romania

\begin{abstract}
Identity is also one of the most frequently examined issues in contemporary developmental psychology research. In the literature, we can find various definitions of identity, as well as various theoretical conceptualizations and models.

The present paper describes contemporary models of personal identity, provides the definitions of the notions (as processes/dimensions/styles/modes) included in these models, measurement methods, as well as a review of the research results obtained in these various theoretical paradigms. The review includes multiple approaches - from Marcia's classical identity status paradigm, through neo-Eriksonian models (such as the three and five dimensional models, identity styles, identity processes in adulthood) up to narrative views. Finally, we present conclusions based on the analyses of these models and implications for future research and theory.
\end{abstract}

IDENTITY

DENTITY STATUSES

IDENTITY STYLES

IDENTITY DIMENSIONS

IDENTITY PROCESSES

IDENTITY MODES

EXPLORATION

COMMITMENT

6 IDENTITY IN PSYCHOLOGY - DEFINITION AND HISTORICAL VIEW

6 Various Definitions of Identity

7 Personal Identity Theories - The Background

9 CONTEMPORARY NEO-ERIKSONIAN VIEWS OF IDENTITY FORMATION

9 Process-Oriented Models

13 Berzonsky's Social-Cognitive Perspective

14 The Circumplex of Identity Formation Modes

16 Identity in Adulthood - Whitbourne's Identity Processing Theory

17 McAdams' Narrative Identity

19 Eudaimonic Identity - Waterman

20 CONCLUSIONS AND POSSIBLE FUTURE DIRECTIONS

23 REFERENCES 


\section{IDENTITY IN PSYCHOLOGY - DEFINITION AND HISTORICAL VIEW}

\section{VARIOUS DEFINITIONS OF IDENTITY}

dentity research is a rapidly growing area of psychological literature. The term identity is indexed 33,687 times in the EBSCO database, based on the titles of the papers (as of 2018). It is almost half as popular as personality, which is probably one of the most frequently used terms in psychology (more than 71,000 articles included this word in their titles). Despite the fact that it is one of the most popular terms in psychological research, there is probably not a single and widely accepted definition of identity.

Historically and philosophically, the term identity derives from a notion of identical and

IDENTITY IN PSYCHOLOGY:

Answer to the question "Who am I?" was considered as "being the same, or alike, in all respects (identical)" (Drever, 1947, p. 128) and even more contemporary sources define identity theories as: "an approach to the mindbody problem, a form of materialism holding that mental states have no separate existence but are identical to physical brain states" (Coleman, 2003, p. 353). In their dictionary of psychology, Reber, Allen, and Reber (2009) define identity, when treated as a notion from personality theories, as a subjective perceiving oneself as unique, the essence of a person, linked with the continuous self. In the APA Dictionary of Psychology (VandenBos, 2007), we can find similar definition:

\begin{abstract}
an individual sense of self defined by (a) physical, psychological, and interpersonal characteristics that is not wholly shared with any other person and (b) a range of affliations (e.g. ethnicity) and social roles. Identity involves a sense of continuity, or the feeling that one is the same person today that one was yesterday or last year (despite physical or other changes). Such a sense is derived from one's body sensations; one's body image; and the feeling that one's memories, goals, values, expectations, and beliefs belong to the self (p. 519).
\end{abstract}

The current paper reviews the most prevalent personal identity theories and research. Personal identity (also called individual identity) can be described as a self-definition, made, developed or created by an individual (Vignoles, Schwartz, \& Luyckx, 2011). This definition may be composed of various factors: aims, desires, goals, values, ideology, beliefs, etc. In line with the dual distinction in identity research, personal identity theories are mainly focused on these factors (also called the content of identity) and the processes individuals use to develop their identity, in order to make the distinction between identity content and identity processes.

Identity is also a concept in everyday language. Non-psychological sources, such as the Collins Dictionary (2016) define identity as answer to the question "Who am I?" and the characteristics that distinguish one person from others. This definition can be treated as most adequate for contemporary personal identity theories that will be described in this paper. This definition is also consistent with Matsumoto's psychological dictionary (2009), where identity is explained as "the way individuals understand themselves and are recognized by others" (Matsumoto, p. 244). This dictionary also defines personal identity as the beliefs about characteristics that distinguish individuals from other people. Alongside personal identity, Matsumoto also lists for example collective, rational, and gender identities. Identity formation is, in turn, defined as the process of forming "a stable sense of self" (p. 246), including commitment to various life roles and beliefs about human life.

One of the first comprehensive identity handbooks (Schwartz, Luyckx, \& Vignoles, 2011) also defines identity as the answer to the question "Who am I?". This answer may 
refer to such aspects as a sense of belonging to a given group, roles played in society, relations with other people, self-definitions, etc. Schwartz et al. (2011) distinguish individual or personal identity (linked with self-definitions), relational identity (connected with roles towards other people), and collective identity (group identification). The present review focuses on contemporary views of personal identity.

According to Vignoles et al. (2001), a few important questions should be raised when researching identity: Is it stable or fluid? Is it individual or collective? Is it discovered by the individual during development or is it constructed? And finally, should it be examined using qualitative or quantitative methods? Moreover, during research design another set of questions could be asked: What developmental stage will be studied? What domains of identity formation will studies focus on? How will detailed identity formation processes be examined? How many variables will be needed? Various identity formation models provide different answers to these questions. The choice of model for conducting research depends on the research question and the sample. Below, we present identity formation models and measurement tools designed to assess the variables distinguished in these models, as well as the most important research findings based on these models. We chose to focus on identity models that are often cited and verified in the contemporary literature on identity development.

\section{PERSONAL IDENTITY THEORIES - THE BACKGROUND}

One theory important for understanding further identity views and concepts is Havighurst's (1948) developmental tasks theory. Havighurst defined developmental tasks as the tasks appearing in certain life stages. Achieving these tasks contributes to individuals' happiness and success, whereas not overcoming them is a factor for disappointment and failure in later tasks and later life.

Havighurst distinguished six life stages: infancy and early childhood, middle childhood, adolescence, early adulthood, middle age, and later maturity. Each life stage has specific requirements and tasks. Adolescence is the key stage for identity development according to Havighurst. During adolescence, individuals have to build mature peer relationships, shape their gender role, accept their own appearance, achieve independence from their parents and other adults, prepare for starting a family and occupational career, and develop their own ideology. These tasks are inseparably connected to identity formation.

A later theory that is also highly important for the contemporary understanding of identity formation and is also related to developmental stages and life tasks an individual has to deal with is Erikson's $(1950,1968,1980)$ psychosocial theory of human development. According to Erikson, human development is a sequence of life crises, specific to each life stage. One crisis has to be overcome to achieve further satisfactory development. Among eight life dilemmas (Trust versus Mistrust, Autonomy versus Shame, Initiative versus Guilt, Industry versus Inferiority, Identity versus Role Confusion, Intimacy versus Isolation, Generativity versus Stagnation, Ego Integrity versus Despair) the fifth, Identity versus Role Confusion, takes place in adolescence. Erikson considered adolescence to be crucial for developing ego identity and identity crisis is defined as the period of exploring various life roles.

Adolescence is a time for integrating and shaping ego identity. Young people are in the stage that Erikson (1950) called moratorium - the phase between adolescence and adulthood, between the things that a young person has learned as a child (that are no longer satisfactory) and the things that he or she can learn in adult life. According to Erikson, identity formation neither starts, nor ends in adolescence. However, adolescence is crucial for this task, as this is the time when the question "Who am I?" arises. The answer to this question can help individuals manage various life requirements, despite life and individual changes.

ERIKSON'S PSYCHOSOCIAL THEORY OF HUMAN DEVELOPMENT:

Eight life crises individual has to overcome Identity - fifth crisis 
The sense of identity can be loose and be further shaped in adulthood, however it should be first developed in adolescence. Nowadays, much research also considers Emerging Adulthood (Arnett, 2000), which spans from the late teens through the twenties, and is also considered an important period for solving identity issues. This period (the question whether it should be treated as a separate developmental stage is still open) is characterized by feeling in-between adolescence and adulthood, and is related to postponing adult commitments.

Erikson's view of identity was operationalized and further developed by Marcia (1966), who defined identity as a kind of a self-structure, composed of human beliefs, ideology, goals, and values. Marcia proposed the identity status paradigm, wherein identity structure is based on two pivotal categories: exploration (firstly called crisis) and commitment. On the one hand, exploration is understood as actively seeking alternatives available in the individual's current environment and recognizing the relationships and individual resources present in this environment. Commitment, on the other hand, is a decision or choice made in an identity relevant area. This is the choice of the life path an individual wants to follow and it requires assuming responsibility for this decision.

Marcia expanded Erikson's dilemma Identity versus Identity Confusion to four possibilities: identity achievement, identity diffusion, identity moratorium, and identity foreclosure. These possibilities were called identity statuses and are based on the presence or absence of the two categories: commitment and exploration. The identity statuses proposed by Marcia are presented and described in Table 1 .

TABLE 1. Marcia's identity status paradigm - the descriptions of the four statuses

\begin{tabular}{|c|c|c|c|}
\hline Status & $\begin{array}{l}\text { Com } \\
\text { explor }\end{array}$ & $\begin{array}{l}\text { and } \\
\text { urance }\end{array}$ & Description \\
\hline Achievement & $\begin{array}{l}\text { Commitment } \\
\text { Exploration }\end{array}$ & YES & $\begin{array}{l}\text { In the achievement status, there is a commitment to an important life choice, after } \\
\text { experiencing the crisis of exploration. The choice is consistent with personal needs, } \\
\text { values, and feelings. The achieved identity is stable and resistant to changes in the } \\
\text { environment and new responsibilities. In achievement, the individual knows who } \\
\text { she or he wants to be and what life path to take, is aware of his/her own capacities, } \\
\text { restrictions, environmental requirements, etc. }\end{array}$ \\
\hline Foreclosure & $\begin{array}{l}\text { Commitment } \\
\text { Exploration }\end{array}$ & YES & $\begin{array}{l}\text { In the foreclosure status, the individual does not explore, however, she or he ap- } \\
\text { pears to be committed to current identity decisions. Sometimes this is the result of } \\
\text { internalizing the expectations of significant others. Identity foreclosure is connected } \\
\text { to conformism. }\end{array}$ \\
\hline Diffusion & $\begin{array}{l}\text { Commitment } \\
\text { Exploration }\end{array}$ & NO & $\begin{array}{l}\text { The diffusion status is characterized by the lack of commitment. Even when there } \\
\text { are some commitments, they are loose or easily changed by the individual. Identity } \\
\text { diffusion is linked to anxiety or a fear of entering relationships, which can result in } \\
\text { difficulties in school or in daily life. }\end{array}$ \\
\hline Moratorium & $\begin{array}{l}\text { Commitment } \\
\text { Exploration }\end{array}$ & $\begin{array}{l}\text { NO } \\
\text { YES }\end{array}$ & $\begin{array}{l}\text { In the moratorium status, commitment is unclear and various possibilities are inten- } \\
\text { sively explored. It is a time of frequent changes, of seeking new activities, which can } \\
\text { sometimes be inconsistent. Social support is very important in this status. }\end{array}$ \\
\hline
\end{tabular}

Research has shown that identity statuses are different in terms of personality (for a review see: Kroger \& Marcia, 2011): achievement was reported to be related to high extroversion, emotional stability, conscientiousness, openness to experience, and low levels of psychosocial problems. Foreclosure was characterized by low openness to experience and a low level of psychosocial problems. Moratorium was linked to high openness to experience, low emotional stability, low conscientiousness, and a high level of psychosocial problems. Finally, individuals in the diffusion status were characterized by a less adaptive personality profile: low emotional stability, conscientiousness, openness to experiences, and high levels of psychosocial problems. 
Identity statuses can be measured in various ways. The initial identity measures were structured or semi-structured interviews. The Ego Identity Incomplete Sentences Blank (EI-ISB; see: Kroger and Marcia, 2011), was the original tool designed to identify achieved identity. The second method was the Identity Status Interview (ISI; Marcia, 1966), designed to capture the presence of the two identity processes: commitment and exploration. Finally, probably the most frequently used self-report questionnaire designed for measuring statuses is the Extended Objective Measure of Ego Identity Status II (EOM-EIS-II; Marcia, 1993) that has been validated in various languages version such as English, Spanish, or Swedish (see: Schwartz et al, 2006). Erikson's psychosocial theory is the foundation of contemporary approaches to identity. It emphasizes the importance of adolescence for overcoming identity crisis by answering the question "Who am I?", but also it highlights that this question may appear again at various life stages. This approach, along with Marcia's identity operationalization, initiated the contemporary trend of research on identity.

\section{CONTEMPORARY NEO-ERIKSONIAN VIEWS OF IDENTITY FORMATION}

Erikson and his psychosocial theory introduced the notion of identity to psychological research. On the basis of his work, the following models were proposed: Marcia's (1966) status paradigm, which was further extended into process-oriented models (see: Bosma \& Kunnen, 2001; Crocetti, Rubini, \& Meeus, 2008; Grotevant et al., 1987; Luyckx et al., 2008; Whitbourne, Sneed, \& Skultety, 2002), the social-cognitive model of identity styles (Berzonsky, 1989), the eudaimonic identity model (Waterman, 1982) and, finally, the integrative Circumplex of Identity Formation Modes model (Cieciuch \& Toplewska, 2017; Topolewska \& Cieciuch, 2017). McAdams $(1985,1993)$ also provides another perspective on Erikson's identity theory with the model of personality within the narrative identity paradigm. All models are discussed in the following sections.

\section{PROCESS-ORIENTED MODELS}

The process-oriented models are mainly focused on the processes individuals use to develop their identity, rather than on categorizing people into various statuses. One of the first steps to elaborate on Marcia's theory was made by Bosma $(1985,1986)$ who differentiated between commitment making and identification with commitment as the fact that individual has made a commitment in an identity relevant domain does not necessarily means that he or she identifies with this commitment. Grotevant (1987) was one of the first who published process-oriented identity view and highlighted that identity is being developed in various life domains. Then, the model proposed by Stephen, Fraser, and Marcia (1992) described the cycles of moratorium-achievement (MAMA) and showed that in identity formation there is a continuous cycle of commitment and exploration, occurring one after another. Later, another important differentiation was made: Meeus and colleagues (2002) highlighted the role of exploration in maintaining an individual's commitments and suggested that the exploration process plays a role in managing current commitments. Meanwhile, Meeus (1996) proposed the reinterpretation of exploration and commitment as dimensions with the possibility of low or high levels instead of occurrence or lack thereof, as Marcia did.

Based on these findings, the two most frequently examined process-oriented models were developed. One includes three and the other includes five identity processes, instead of the two proposed by Marcia. The first of these two well-examined process-oriented models 
derived from Marcia's theory was proposed by Luyckx and colleagues (Luyckx, Goossens, \& Soenens, 2006; Luyckx, Goossens, Soenens et al., 2006), and the second by Crocetti and colleagues (Crocetti, Rubini, \& Meeus, 2008; Crocetti, Rubini, Luyckx, et al., 2008). Both models are described below.

Luyckx et al.'s Five-Dimensional Model. The five-process model proposed by Luyckx and colleagues (Luyckx, Goossens, \& Soenens, 2006; Luyckx, Goossens, Soenens et al., 2006; Luyckx et al., 2008) includes two identity cycles: identity formation and identity evaluation. The identity formation cycle includes commitment making and exploration in depth. Commitment making is an identity decision. Moreover, one can identify with the commitment or not (identification with commitment). In-depth exploration is gathering information about an existing commitment, while exploration in breadth is gathering information about other possibilities. Identity evaluation (maintenance) includes the interplay between identification with commitment making and in-depth exploration. The cycles are visualised in the Figure 1. Initially, the model included four identity processes (Luyckx et al., 2005) and the fifth identity process, ruminative exploration, was proposed later (Luyckx, Goossens, \& Soenens, 2006; Luyckx, Goossens, Soenens et al., 2006; Luyckx et al., 2008). Ruminative exploration, which is not included in the cycles, is a maladaptive form of exploration, related to ruminative thinking. The processes are described in Table 2.

Table 2. Identity processes in Luyckx et al.'s model

Five identity processes

and two cycles

(identity formation and identity evaluation)

\begin{tabular}{|c|c|c|}
\hline Construct & Description & Correlates/Research results \\
\hline Commitment making & $\begin{array}{l}\text { A decision made in an identity important } \\
\text { domain. }\end{array}$ & $\begin{array}{l}\text { - } \text { Adjustment (Mannerström et al., 2016) } \\
\text { - Low neuroticism (Luyckx et al., 2006) } \\
\text { - Parenting (Soenens, Luyckx, Vansteenkiste, \& Goossens, 2008) } \\
\text { - High personal standards perfectionism, low maladaptive } \\
\text { perfectionism (Luyckx, Soenens, Goossens, et al., 2008) }\end{array}$ \\
\hline $\begin{array}{l}\text { Identification with } \\
\text { Commitment }\end{array}$ & $\begin{array}{l}\text { The extent to which one identifies with } \\
\text { the decision made in an identity important } \\
\text { domain, feeling certain about existing } \\
\text { commitments. }\end{array}$ & $\begin{array}{l}\text { - Positive adjustment and good relationships with other people } \\
\text { (Luyckx, Goossens, \& Soenens, 2006; Mannerström, 2016) } \\
\text { - High personal standards perfectionism, low maladaptive } \\
\text { perfectionism (Luyckx, Soenens, Goossens, et al., 2008) }\end{array}$ \\
\hline $\begin{array}{l}\text { Exploration } \\
\text { in Depth }\end{array}$ & $\begin{array}{l}\text { Gathering information about existing com- } \\
\text { mitments, exploring current choices. }\end{array}$ & $\begin{array}{l}\text { - Adjustment, high extroversion (Luyckx, Goossens, Soenens et } \\
\text { al., 2006) } \\
\text { - Self-reflection (Luyckx et al., 2008) } \\
\text { - Anxiety (Luyckx et al., 2008) }\end{array}$ \\
\hline Exploration in Breadth & $\begin{array}{l}\text { Gathering information about possible } \\
\text { commitments, alternatives to choices that } \\
\text { have already been made, weighing various } \\
\text { commitment options. }\end{array}$ & $\begin{array}{l}\text { - Low adjustment (Luyckx, Goossens, Soenens et al., 2006) } \\
\text { - Self-reflection (Luyckx et al., 2008) } \\
\text { - Neuroticism and extroversion (Luyckx, Goossens, Soenens et } \\
\text { al., 2006) } \\
\text { - Depressive symptoms and low self-esteem (Schwartz et al., } \\
\text { 2009) }\end{array}$ \\
\hline $\begin{array}{l}\text { Ruminative } \\
\text { Exploration }\end{array}$ & $\begin{array}{l}\text { A type of exploration linked with problems } \\
\text { with making decision, ruminative thinking, } \\
\text { and worrying. }\end{array}$ & $\begin{array}{l}\text { - Distress, depression, ruminative thinking, low well-being, low } \\
\text { self-esteem (Luyckx et al., 2008) } \\
\text { - Maladaptive perfectionism (Luyckx, Soenens, Goossens, et } \\
\text { al., 2008) }\end{array}$ \\
\hline
\end{tabular}

Based on these processes, five identity statuses can be empirically derived (Luyckx et al., 2005): achievement, moratorium, foreclosure, troubled diffusion, and carefree diffusion. The first three statuses are similar to those proposed by Marcia. The main differences are in the diffusion status, namely carefree diffusion which is characterized by low levels of exploration 
processes and low to moderate commitment processes. The Dimensions of Identity Development Scale (DIDS; Luyckx et al., 2008) is designed to measure the five identity processes. The tool is 25 -item self-report questionnaire, measuring identity processes related to an individual's plans for the future. The DIDS questionnaire has been validated in a variety of different countries, such as Greece, Turkey, and Japan (see: Mastrotheodoros \& Motti, 2016; Morsunbul \& Cok, 2014; Nakama et al., 2015).

Crocetti et al's Three-Factor Identity Model. This model includes three pivotal identity processes: commitment, in-depth exploration, and reconsideration of commitment and it is focused on the extent to which an individual explores and commits to identity relevant choices, as opposed to solely focusing on the presence or absence of these processes. The definitions of these processes and their correlates are presented in Table 3. According to this model, there are two cycles in the process of identity development: identity formation (including reconsideration of commitment and commitment) and identity maintenance, including commitment and in-depth exploration (Crocetti, 2017). The similarities and differences between two dual-cycle models are presented in Figure 1.

Table 3. Identity processes in Crocetti et al.'s model

\begin{tabular}{|c|c|c|}
\hline Construct & Description & Correlates/Research results \\
\hline Commitment & $\begin{array}{l}\text { The decisions made by individuals in } \\
\text { identity important life domains, and } \\
\text { the extent to which one identifies with } \\
\text { these decisions. }\end{array}$ & $\begin{array}{l}\text { - Extraversion, emotional stability, high self-esteem (Crocetti, Rubini, } \\
\text { Luyckx, et al., 2008) } \\
\text { - Well-being (Karaś, et al., 2015) } \\
\text { - Positive relationships with others (Crocetti et al., 2017) } \\
\text { - Adjustment (Crocetti et al., 2009, 2013) }\end{array}$ \\
\hline $\begin{array}{l}\text { In-depth } \\
\text { Exploration }\end{array}$ & $\begin{array}{l}\text { Actively seeking information about } \\
\text { existing commitments, talking with } \\
\text { other people about existing commit- } \\
\text { ments, etc. }\end{array}$ & $\begin{array}{l}\text { - Openness to experience, agreeableness, conscientiousness (Crocetti } \\
\text { et al., 2010) } \\
\text { - Well-being and satisfaction with life (Karaś et al., 2015, Sugimura } \\
\text { et al., 2015) } \\
\text { - Positive relationships with others (Crocetti et al., 2017) } \\
\text { - Low emotional stability and high problematic behaviors (Crocetti, } \\
\text { Rubini, Luyckx, et al., 2008) }\end{array}$ \\
\hline $\begin{array}{l}\text { Reconsideration } \\
\text { of Commitment }\end{array}$ & $\begin{array}{l}\text { A comparison between current } \\
\text { commitments and other possibilities, } \\
\text { as well as an individual's efforts to } \\
\text { change existing commitments, when } \\
\text { they are no longer satisfactory.. }\end{array}$ & $\begin{array}{l}\text { - Low extraversion and agreeableness (Crocetti, Rubini, Luyckx, et al., } \\
\text { 2008) } \\
\text { - Low well-being (Karaś et al., 2015) } \\
\text { - Problems with relationships (Crocetti et al., 2017) } \\
\text { - Problematic behaviors (Crocetti et al., 2013) }\end{array}$ \\
\hline
\end{tabular}

Based on these three processes, Crocetti, Rubini, Luyckx, et al. (2008) empirically derived five identity statuses: achievement, early closure, moratorium, searching moratorium, and diffusion. Achievement is characterized by high commitment, in-depth exploration, and low reconsideration of commitment. Early closure is characterized by a moderate-to-high level of commitment and low levels of exploration and reconsideration of commitment. The main difference in the statuses between this theory and Marcia's view are the two types of moratorium: one more adaptive and the other less adaptive. People in moratorium are characterized by a low level of commitment and a low to moderate level of reconsideration of commitment. People in the searching moratorium status have high levels of all three identity processes. Finally, diffusion is characterized by low levels of all three processes.

CROCETTI ET AL.:

Three identity processes and two cycles (identity formation, identity maintenance) 


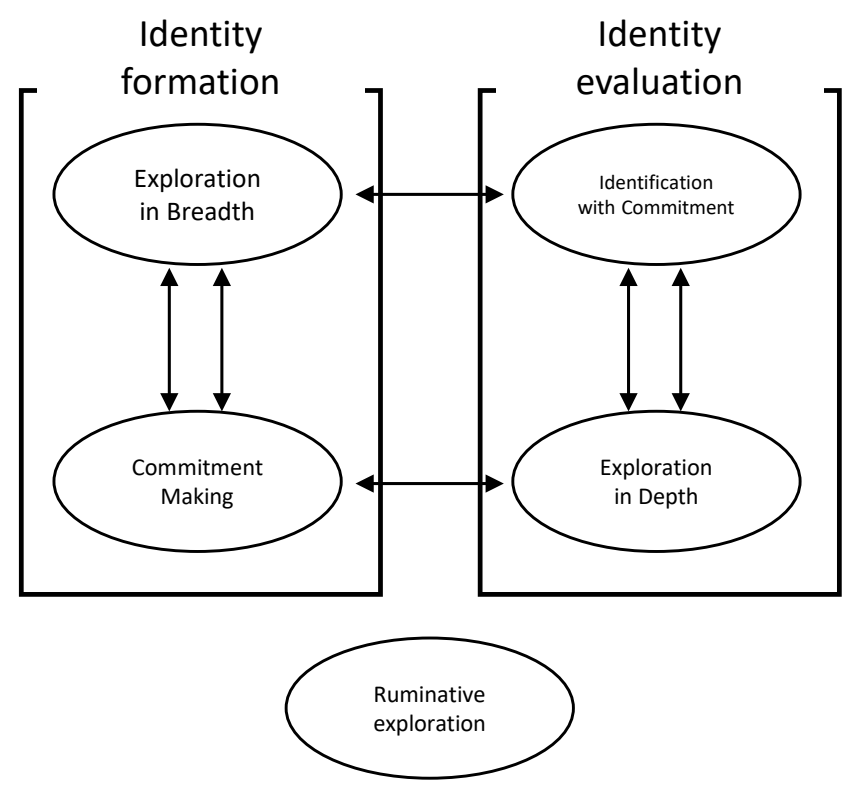

(Luyckx, Goossens, Soenens et al., 2006; Luyckx et al., 2008)

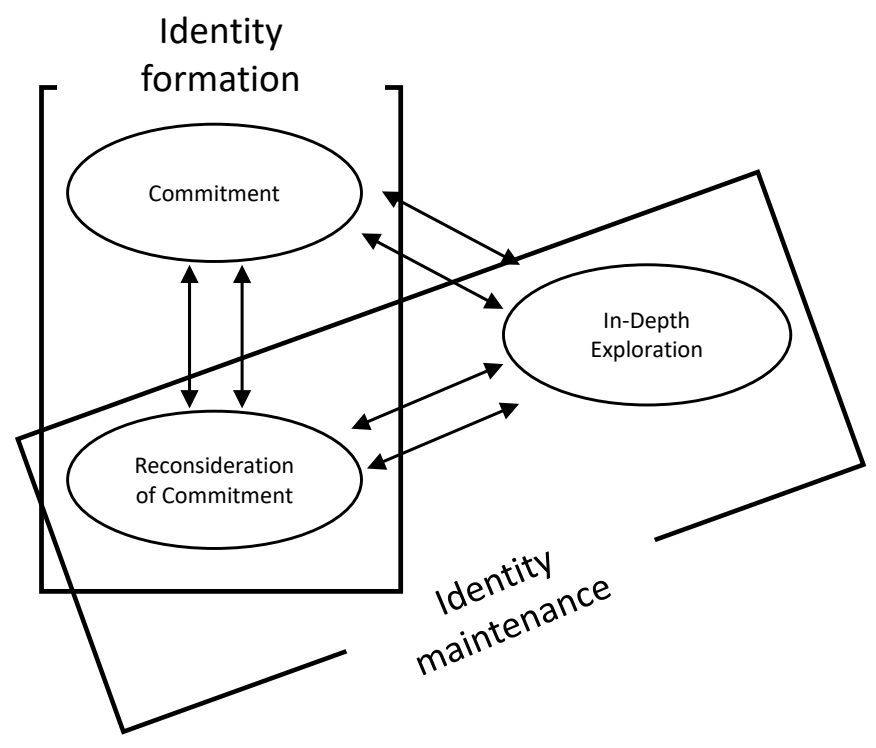

(Crocetti, Rubini, \& Meeus, 2008; Crocetti, Rubini, Luyckx et al., 2008)
BERZONSKY:

Three identity styles
Figure 1. Two cycles of identity in two conceptualizations

The first tool developed to measure the identity processes conceptualized in this theory was the Utrecht-Groningen Identity Development Scale (U-GIDS; Meeus, 1996), including commitment and in-depth exploration. When the theory was complemented by reconsideration of commitment, a new 13-item tool based on the U-GIDS, was developed: the Utrecht Management of Identity Commitment Scale (U-MICS; Crocetti, Rubini, Luyckx, et al., 2008). Both questionnaires are self-report tools and enable measuring identity processes in various domains. The U-MICS questionnaire was validated in various countries and cultures, such as: Bulgaria, Czech Republic, China, Greece, Italy, Japan, Kosovo, the Netherlands, Poland, Portugal, Romania, Slovenia, Switzerland, Taiwan, and Turkey (see: Crocetti et al., 2015; Dimitrova et al., 2015, Llorent \& Alamo, 2018). Inspired by the three-factor model and U-MICS questionnaire, Karaś \& Cieciuch (2015) modified the original U-MICS scale by adding bi-directional scoring to the commitment subscale and including eight identity domains previously identified in qualitative studies to be the most important for identity in emerging adulthood - the number of items per domain was unchanged. The proposed tool is called the Warsaw Management of Identity Commitment Scale (W-MICS).

The two process-oriented identity models described above are schematically presented in Figure 2. The main difference between these models is the operationalization of the identity formation cycle (Crocetti, 2017). In the three-factor identity model, adolescents have some preliminary commitments. In the five-dimensional model (which is more similar to Marcia's view), identity formation starts without any preliminary commitments. 


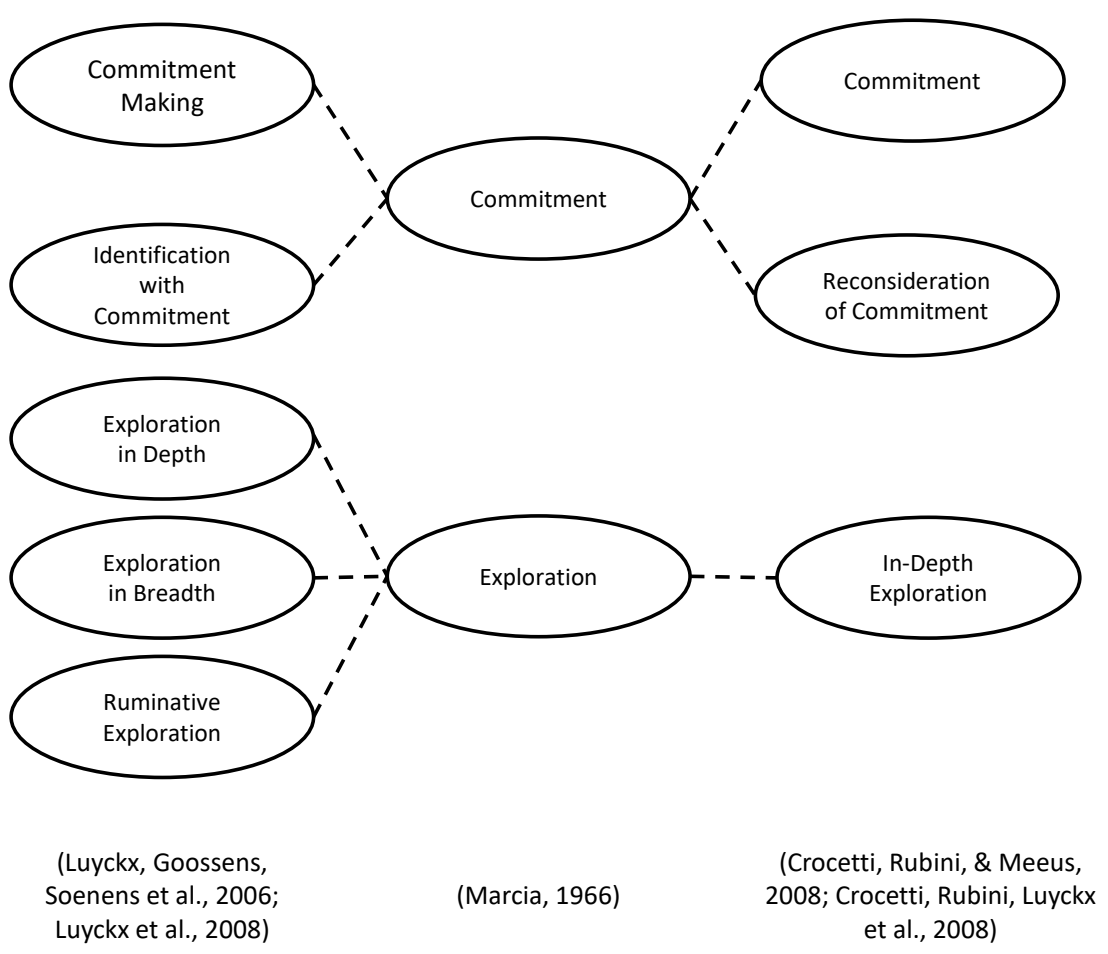

Figure 2. Identity processes in a Neo-Eriksonian perspective

\section{BERZONSKY'S SOCIAL-COGNITIVE PERSPECTIVE}

Rather than treating identity as a dilemma of one life stage, Berzonsky $(1989,2003,2004)$ proposed identity as an implicit self-theory (see: Kelly, 1955), composed of personal constructs and self-representations that the individual creates. Berzonsky introduced a cognitive aspect into identity formation and even related it to Descartes' theory: who we are is determined by our cognitive processes - thinking and doubting. Unlike other identity theories, Berzonsky focuses on adulthood in addition to adolescence.

Berzonsky's model focuses on the social-cognitive strategies used by individuals in the process of identity development. According to Berzonsky, identity can be considered as both a structure and a process. People organize their personal constructs (the process) and synthesize them into cognitive theories (the structure). People are self-theorists and their theories include their behaviours and experiences, values and goals, ideologies, life requirements, and the whole history of their life. People differ in the manner that they approach or avoid identity tasks and these differences play an important role in solving problems and making decisions.

Berzonsky distinguished three styles used by individuals in the process of identity formation: informative, normative, and diffuse-avoidant styles. They are described in Table 4. These styles can be seen as similar to Marcia's statuses: informative to achieved identity or moratorium, normative to foreclosure, and diffuse-avoidant to identity diffusion. 
Table 4. Identity styles in Berzonsky's theory

\begin{tabular}{|c|c|c|}
\hline Construct & Description & Correlates/Research results \\
\hline Normative Style & $\begin{array}{l}\text { Adopting expectations, values, and aims } \\
\text { from significant others. Protection of } \\
\text { self-concept from discrepant information. } \\
\text { Small tolerance for ambiguity of information, } \\
\text { high need for cognitive closure, automatic } \\
\text { approach to self-theory, stiffness, and } \\
\text { resistance to changes. }\end{array}$ & $\begin{array}{l}\text { - Conscientiousness (Dollinger \& Clancy Dollinger, 1997; } \\
\text { Duriez \& Soenens, 2006) } \\
\text { - Low openness to experience (Dollinger \& Clancy Dollinger, } \\
\text { 1997; Duriez \& Soenens, 2006) } \\
\text { - High self-esteem (Luyckx et al. 2007) } \\
\text { - Universalism (Berzonsky, Cieciuch, Duriez, \& Soenens, } \\
\text { 2011) }\end{array}$ \\
\hline Informative Style & $\begin{array}{l}\text { Active seeking, self-reflection, informative } \\
\text { orientation, constantly learning new things } \\
\text { about the self, sceptical thinking, openness } \\
\text { to new information, criticism. }\end{array}$ & $\begin{array}{l}\text { - Openness to experiences, flexibility, well-being (Vleioras } \\
\text { \& Bosma, 2005) } \\
\text { - Need for cognition (Berzonsky \& Sullivan, 1992) } \\
\text { - Success expectations and seeking social support (Nurmi, } \\
\text { Berzonsky, \& Tammi, 1997) } \\
\text { - Conformity and tradition (Berzonsky et al., 2011) }\end{array}$ \\
\hline Diffuse Avoidant Style & $\begin{array}{l}\text { Procrastination and defensive avoidance } \\
\text { of situations that require decision making. } \\
\text { External locus of control, egocentrism, and } \\
\text { present orientation.. }\end{array}$ & $\begin{array}{l}\text { - Low well-being (Vleioras \& Bosma, 2005) } \\
\text { - Low conscientiousness (Dollinger \& Clancy Dollinger, } \\
\text { 1997; Duriez \& Soenens, 2006) } \\
\text { - Task-irrelevant behavior (Nurmi, Berzonsky, \& Tammi, } \\
\text { 1997) } \\
\text { - Hedonism (Berzonsky et al., 2011) }\end{array}$ \\
\hline
\end{tabular}

Structural analyses of identity formation styles showed that the diffuse-avoidant style could be divided into two more detailed constructs: diffuse-carefree and avoidant styles (Cieciuch, 2010; Topolewska \& Cieciuch, 2015). The former reflects identity formation without worrying about identity-relevant issues and purpose in life and is positively related to emotional stability. The latter is full of conformism and anxiety and contains a sense of being lost in the world and is negatively related to emotional stability and self-acceptance. These results are in line with the research described above that distinguished two types of diffuse statuses: diffused diffusion and carefree diffusion (Luyckx et al., 2008).

Identity processing styles can be measured by the Identity Style Inventory (ISI-5; Berzonsky et al., 2013), a 39-item self-report tool consisting of three scales, one for each of the informational, normative, and diffuse-avoidant styles. The items refer to life situations more generally rather than to any specific domain. During past decades the ISI has been validated in more than twenty countries throughout the world (see: Berzonsky et al., 2013).

\section{THE CIRCUMPLEX OF IDENTITY FORMATION MODES}

Considering the diversity of identity formation models, Cieciuch and Topolewska (2017) proposed an integration of the models stemming from the Erikson-Marcia tradition within the Circumplex of Identity Formation Modes (CIFM). On the basis of a theoretical analysis of identity formation variables from the models described above, they distinguished eight circularly organized constructs: Socialization, Consolidation, Exploration, Moratorivity, Defiance, Diffusion, Petrification, and Normativity. The constructs considered in the theoretical development of the CIFM were: exploration and commitment along with four identity formation statuses by Marcia (1966); commitment, in-depth exploration, and reconsideration of commitment from Crocetti, Rubini, and Meeus (2008) model; identification with commitment, commitment making, exploration in depth, exploration in breadth, and ruminative exploration by Luyckx et al. (2008); informative, normative, and diffuse-avoidant 
identity processing styles from Berzonsky's (1989) model. The descriptions of proposed constructs are presented in Table 5 .

Table 5. Characteristics of the Identity Formation Modes (Topolewska \& Cieciuch, 2017)

\begin{tabular}{|c|c|}
\hline Mode & Description \\
\hline Socialization & $\begin{array}{l}\text { Defining oneself in such a way as to perform one's life roles well, according to the current stage in one's life. Beliefs } \\
\text { concerning oneself form a coherent and stable system associated with a sense of being in the right place. }\end{array}$ \\
\hline Consolidation & $\begin{array}{l}\text { Using information derived from the exploration of different options for building a relatively stable identity structure. The } \\
\text { individual does undertake long-term commitments but he/she is still open to other options and thus may modify them. }\end{array}$ \\
\hline Exploration & $\begin{array}{l}\text { Using information derived from the exploration of different options for building a relatively stable identity structure. The } \\
\text { individual does undertake long-term commitments but he/she is still open to other options and thus may modify them. }\end{array}$ \\
\hline Moratorivity & $\begin{array}{l}\text { Actively seeking one's place in life by exploration, combined with commitments and engagements to ascertain whether } \\
\text { they will be suitable for oneself in various respects. This quest is associated with a desire for a permanent commitment, } \\
\text { which may give rise to tensions given the temporary nature of one's current commitments. }\end{array}$ \\
\hline Defiance & $\begin{array}{l}\text { The belief that one has not found one's place in life. Because this mode is located between Diffusion (identity indetermi- } \\
\text { nation) and Moratorivity (desire to undertake a commitment), it poses the risk that the adopted commitment will be in } \\
\text { stark opposition to social norms. }\end{array}$ \\
\hline Diffusion & $\begin{array}{l}\text { A lack of a stable identity structure and being motivated in one's actions, beliefs, and decisions by situational variables } \\
\text { and the environment rather than a cognitive identity structure. }\end{array}$ \\
\hline Petrification & $\begin{array}{l}\text { A lack of interest in thinking about oneself and developing an identity structure. The characteristic feature is fragmenta- } \\
\text { tion of a rather poorly developed cognitive identity structure, with the fragmented elements being rigid or even frozen. }\end{array}$ \\
\hline Normativity & $\begin{array}{l}\text { Forming the structure of identity based on the expectations of others. These expectations are not assessed, but rather } \\
\text { uncritically adopted, which may be associated with certain cognitive rigidity and distortion. }\end{array}$ \\
\hline
\end{tabular}

In the CIFM, identity formation modes are used as the basic descriptor for different methods of identity formation. These modes are defined as a type of identity management; people can exhibit tendencies towards particular modes and switch between them while dealing with identity-relevant issues. The CIFM attempts to integrate the identity formation variables from different theoretical perspectives. The foundation for the circumplex model lays on the two basic dimensions, similar to those proposed by Marcia: exploration and commitment. Figure 3 presents the theoretically assumed and empirically confirmed relations between modes and others identity formation constructs. 


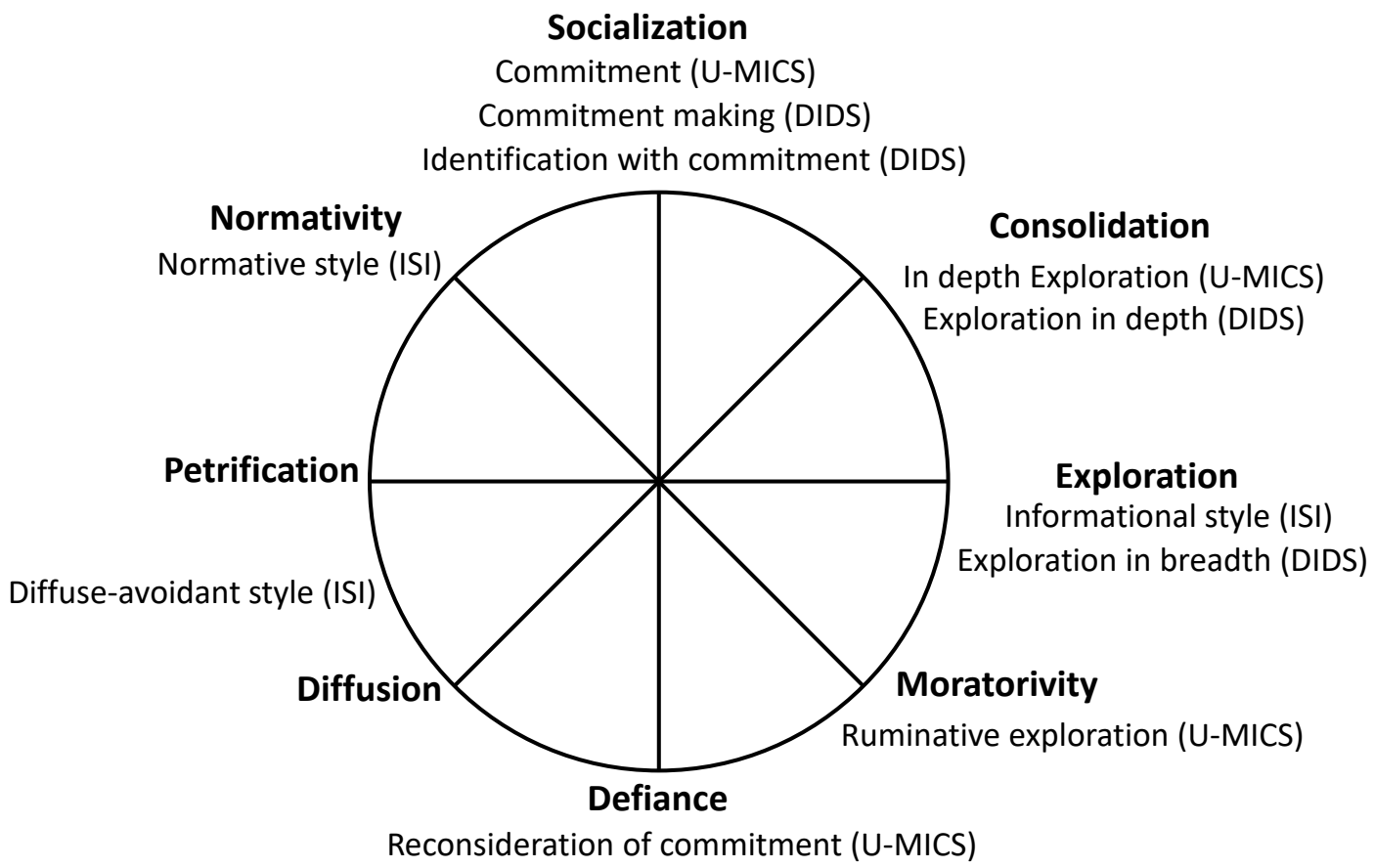

Figure 3. The relations between identity formation constructs from the Erikson-Marcia tradition (Topolewska \& Cieciuch, 2017)

The Circumplex Identity Modes Questionnaire (CIMQ; Topolewska \& Cieciuch, 2017) was designed to measure the eight identity formation modes. It is a self-report tool consisting of 40 items grouped into eight scales. These indicators assess general identity formation, and are not domain specific.

\section{IDENTITY IN ADULTHOOD - WHITBOURNE'S IDENTITY PROCESSING THEORY}

MCADAMS:

Three levels/layers of personality

The process-oriented models proposed by Crocetti et al. (2008) and Luyckx et al. (2008), mainly placed identity development in adolescence (consistent with Erikson's view). But there are also theories focused on identity development in adulthood. One such theory was proposed by Whitbourne and colleagues (2002).

The model proposed by Whitbourne and colleagues (2002) is similar to the Neo-Eriksonian perspective, but also immersed in the Piagetian tradition. Identity is treated as an individual's self-representation of psychological, social, and psychical functioning in three identity process categories: assimilation, accommodation, and balance.

People who mainly use the assimilation process in shaping their identity include identity-important experiences and information into existing self-schemas, even when they receive discrepant information. Their identity structure is rather fragile, their main processing style is self-enhancement, their self-esteem is rather high, and they can be described using the metaphor of the Egoist. Their natural defences are denial and projection and they have a tendency towards narcissism.

Identity accommodators change their identities when they get new information about the self. Their identity structure is also unstable, because their processing style is self-doubt, and their self-esteem is low. They can be described using the metaphor of the Politician. They have a tendency towards depression.

The perfect situation is a balance between these two processes. People who are identity balanced have a stable identity structure, a realistic processing style, and a high but realistic 
self-esteem. Their characteristic defence is intellectualization, but they have a tendency towards experiencing anxiety. The metaphor used to describe them is the Scientist. Identity processes of assimilation and accommodation could be compared in some respects to Marcia's (1966) commitment and exploration, respectively. Relatedly, the balance between assimilation and accommodation is the ideal outcome, similar to identity achievement in the identity statuses model.

Table 6. Identity processes in Whitbourne's theory

\begin{tabular}{|c|c|c|}
\hline Construct & Description & Correlates/Research results \\
\hline Assimilation & $\begin{array}{l}\text { The process used to maintain self-consistency } \\
\text { even when facing discrepant information or } \\
\text { experiences. }\end{array}$ & $\begin{array}{l}\text { - Negative affect (Whitbourne 1996) } \\
\text { - Social isolation (Whitbourne, Sneed, \& Skultety, 2002) } \\
\text { - High self-esteem (Whitbourne \& Collins, 1998) }\end{array}$ \\
\hline Accommodation & $\begin{array}{l}\text { The process of making changes in identity } \\
\text { structure as a response to new information and } \\
\text { experiences. }\end{array}$ & $\begin{array}{l}\text { - Responsiveness to external influences and overreacting } \\
\text { - Low self-esteem (Whitbourne, Sneed, \& Skultety, 2002) }\end{array}$ \\
\hline Balance & $\begin{array}{l}\text { The optimal dynamic balance between identity } \\
\text { assimilation and accommodation; flexibility. }\end{array}$ & $\begin{array}{l}\text { - High self-esteem (Whitbourne, Sneed, \& Skultety, 2002) } \\
\text { - Optimal aging (Whitbourne \& Connolly, 1999) }\end{array}$ \\
\hline
\end{tabular}

The brief definitions of the identity processes proposed by Whitbourne, as well as the results of the research, are presented in Table 6. The identity processes proposed by Whitbourne can be measured with a self-report tool known as the Identity and Experiences Scale (IES; Whitbourne, Sneed, \& Skultety, 2002). It is a 55-item Likert scale self-report questionnaire consisting of three subscales (identity balance, identity accommodation, and identity assimilation).

\section{MCADAMS' NARRATIVE IDENTITY}

McAdams's (1985) narrative perspective is also derived from Erikson's theory, but it is quite different from theories described above. McAdams treats identity as a life story written by the individual themselves. All individuals are building and creating their life stories based on their own experiences of daily life. According to this approach, identity is an effect of actively constructing one's individual life story.

Identity may be treated as a life story or personal myth (McAdams, 2011). Individuals start to develop this story in adolescence and continue throughout their lifetime. As a story, identity consists of various plots, tales, and characters. McAdams doesn't focus on identity dimensions/processes or statuses, but treats identity more holistically - as a product of living individual life (McAdams, 1985). McAdams draws from a personological tradition, perceiving life as integrated story and highlights that this story may only be analysed within a narrative framework.

McAdams (1995) also claims that individuals can be described at three levels of functioning, which can be treated as the levels or layers of individuality. These levels organize individual differences. The first level consists of dispositional traits: the dimensions of personality. The second level consists of personal concerns, also called personal characteristics or characteristic adaptations: life aims and tasks, defence mechanisms, desires, skills and abilities, values, motivations. Identity formation constructs such as dimensions and styles could be located in the second level (Cieciuch \& Topolewska, 2017; Hatano, Sugimura, \&

WATERMAN:

Eudaimonic identity and personal expressiveness of identity commitment 
Klimstra, 2016; Klimstra, Luyckx, Goossens, Teppers, \& De Fruyt, 2013; Pals Lilgendahl, 2015). The third level consists of evolving life stories - frameworks and constructions of personal identity - internalized and constantly developing. Each level requires its own manner and methods of exploring and researching, and thus, knowing only one of the three levels does not contribute to fully knowing the individual and his or her identity. The definitions of three levels as well as the research results concerning their reciprocal relationships are presented in Table 7.

Table 7. Three levels of human functioning according to McAdams's theory (based on McAdams et al., 2004)

\begin{tabular}{|c|c|c|}
\hline Construct & Description & Correlates/Research results \\
\hline $\begin{array}{l}\text { Level 1: } \\
\text { Dispositional traits }\end{array}$ & $\begin{array}{l}\text { People's general tendencies to particular } \\
\text { behaviors (such as personality traits). }\end{array}$ & $\begin{array}{l}\text { - Level } 1 \text { related to Level } 2 \\
\text { - Big-Five traits (Level 1) related to goals and values } \\
\text { (Level 2) }\end{array}$ \\
\hline $\begin{array}{l}\text { Level 2: } \\
\text { Personal concerns/ } \\
\text { Personal characteristics/ } \\
\text { Characteristic adaptations }\end{array}$ & $\begin{array}{l}\text { People's concerns, aims, desires, beliefs, } \\
\text { and coping mechanisms. }\end{array}$ & $\begin{array}{l}\text { - Motives and goals (Level 2) related to life-narrative } \\
\text { themes (Level 3) } \\
\text { - Goals for power (Level 2) linked to self-mastery, } \\
\text { influencing other people, achieving victories and } \\
\text { social status } \\
\text { - Goals for intimacy related with love friendship, } \\
\text { caring for others, etc. } \\
\text { - Generativity linked to well-being }\end{array}$ \\
\hline $\begin{array}{l}\text { Level 3: } \\
\text { Life stories }\end{array}$ & $\begin{array}{l}\text { Life story including frameworks and con- } \\
\text { structs that are unique for every individual } \\
\text { (identity). }\end{array}$ & $\begin{array}{l}\text { - Identity narrations linked with motives and goals } \\
\text { - Narrative themes linked with openness to experi- } \\
\text { ences, agreeableness, and neuroticism } \\
\text { - High openness to experiences linked with life-narra- } \\
\text { tive complexity, innovativeness } \\
\text { - Agreeableness linked with communion themes in } \\
\text { narrations } \\
\text { - Neuroticism linked with negative narrative tone }\end{array}$ \\
\hline
\end{tabular}

McAdams (1995) described the main characteristics of identity as a life story. First, there are no two identical life stories: they are unique as individuals, they exist inside a person, they are dynamic and evolving. Then, identity as a life story is a quality of the self but it isn't the same thing: identity can be treated as a specific aspect of the self. In fact, identity is the storied self. Importantly, when identity is a story, it has to be interpreted in the terms of stories: narration, plot, characters. Finally, the three levels described above cannot be reduced to one and therein, they can be seen as independent. They are also not hierarchical in order. Identity as a life story integrates an individual's past, present, and future, giving him/her a sense of purpose and meaning. Researchers can explore people's life stories on the third level.

Since identity, according to McAdams's theory, can be examined only with narrative methods, McAdams (1993) developed a life-story interview technique. Using this interview, one can distinguish self-defining memories, prototypical scenes, and nuclear episodes in individuals' narrations (McAdams, 2004). Participants of narrative identity studies are usually asked to write or tell their life-story scenes, including high and low points, turning points, continuity, their most important scenes from various stages of life, earliest memories, life goals, and so on.

Research has shown that individuals who found meaning in suffering and those who revealed personal agency and exploration in their identity narrations experienced higher well-being and better mental health (McAdams \& McLean, 2013). Moreover, the results have shown relationships between narrative identity and personality traits (McAdams et al., 
2004). An emotionally negative tone in identity narrations was linked to neuroticism, communion in narrations with agreeableness, and the complexity of narrations with openness to experience. In narratives, Wilt, Olson, and McAdams (2011) found connections with two higher-order factors of personality structure. Stability (high emotional stability, conscientiousness, agreeableness) and Plasticity (high extraversion and openness to experience) were related to low threat and exploration, respectively. Additionally, identity formation constructs, such as processes and modes, located in the second layer of personality are underpinned by Stability and Plasticity. Namely, Stability underpins the identity commitment constructs and Plasticity underpins the exploration constructs (Hatano et al., 2017, Topolewska-Siedzik \& Cieciuch, 2018; Topolewska-Siedzik, Cieciuch \& Strus, 2018; Wilt et al., 2011).

\section{EUDAIMONIC IDENTITY - WATERMAN}

Waterman (1982) initially focused on Marcia’s (1966) model by proposing patterns and possible identity trajectories over time. He claimed that individuals begin their identity development in diffusion and then can move to foreclosure or moratorium, followed by achievement, or go back to the earlier statuses. In other words, making identity commitments requires moratorium and "moving back" to the "earlier" statuses is always possible. Later, after the status paradigm was criticized for its excessively simplified categorization (Waterman, 2011), Waterman proposed the personal expressiveness of identity commitment as a third dimension of identity, separate from commitment and exploration (Waterman, 1993). Personal expressiveness, according to Waterman (2011), refers to the subjective experience of eudaimonia, the highest state of happiness and it is the effect of an achieved identity. Accordingly, personal expressiveness is highest in the identity achievement status and the lowest in the diffusion status.

In his eudaimonistic identity theory, Waterman starts from Aristotle's conception of eudaimonia, which means living the best, most desirable human life. Sometimes this term is translated simply as "happiness"(Waterman, 2011). In this view, the main aim of the identity formation process is to discover the true nature of an individual, their potential and life purposes and to realise their potential and purposes. Waterman aimed to use the eudaimonist perspective to understand the identity formation process. The key eudaimonic features of identity, according to Waterman, are discovering and evolving human potentials, finding the purpose of human life and implementing these potentials and purposes in daily life.

According to Waterman (2011), identity problems can be resolved in three ways: commitment can be made after active exploration (as in the achievement and moratorium statuses), through identification with other people (as in the foreclosure statuses), or it can be not made and as a result identity questions remain unanswered (as in the diffusion status).

To understand identity formation, researchers should consider intrinsic motivation to be inseparably connected to personal expressiveness. The predictors of achieving eudaimonic identity are self-determination, having a set of skills, and the effort put into this developmental process.

We can also speak about eudaimonic identity commitments (Waterman et al., 2013). They are characterized by the development of an individual's potential, motivating the individual to activity, they provide a sense of purpose, meaning, and direction, and they are subjectively experienced as personally expressive, however they require some effort. The main aspects of Waterman's theory are presented in Figure 4. 


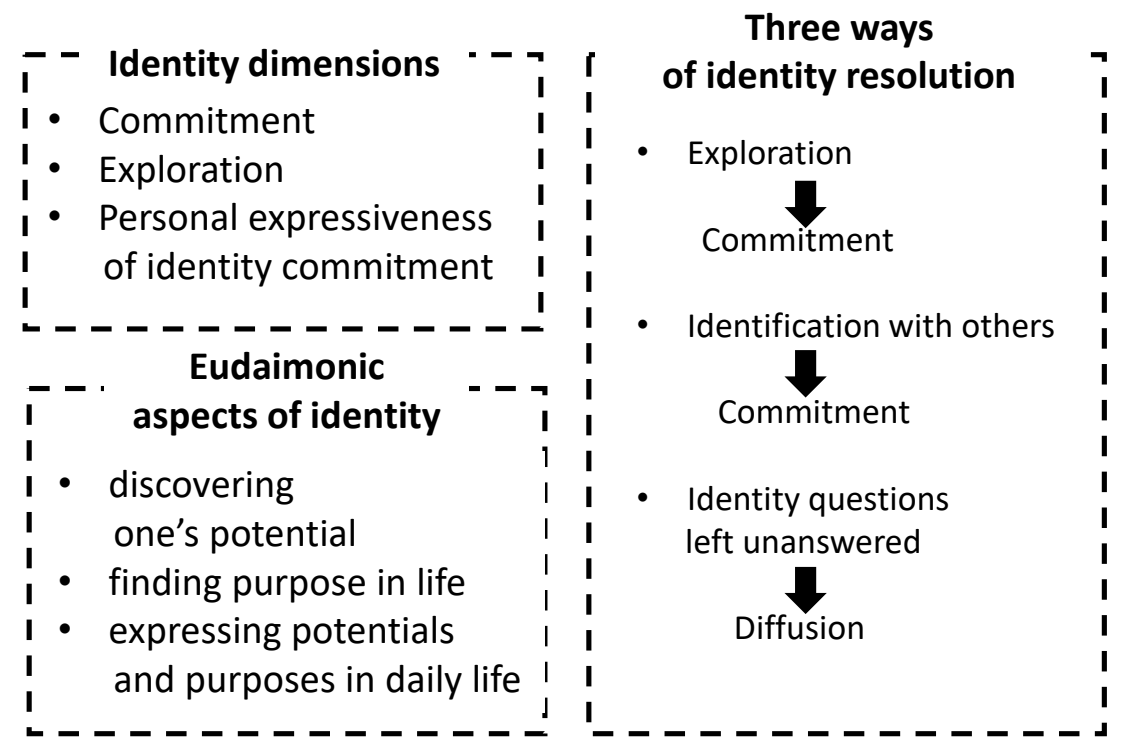

Figure 4. Key elements of eudaimonic identity theory

So far, mixed methods have been used to measure eudaimonic identity (Waterman et al., 2013). Identity processes have been measured using DIDS (Luyckx et al., 2008) and the quality of identity commitments is measured with the Questionnaire for Eudaimonic Well-Being (QEWB; Waterman et al., 2010). The latter questionnaire was designed to measure the extent to which an individual is engaged in activities reflecting identity commitments (Waterman et al., 2013). Research suggests that eudaimonic identity commitments are positive linked to well-being, self-esteem, internal locus of control, and negatively to anxiety and depression (Waterman et al., 2010).

\section{CONCLUSIONS AND POSSIBLE FUTURE DIRECTIONS}

As was shown in the current review, identity is a core concern in contemporary developmental psychology. This area is growing even more rapidly in recent years: new theoretical models are being developed and new questionnaires are being used. Research is extending and it is not only focused on examining the relationships between processes/dimensions/ styles, but also on developmental trajectories in identity formation, as well as the predictors and consequences of identity.

Most of the models discussed in this paper have been examined widely during the last couple of years (for an extended review see: Schwartz, 2011; Schwartz, 2017). Contemporary research has analysed numerous identity correlates (such as personality traits, personal relationships, health, well-being, and adjustment or values preferences) and has been conducted in various countries, even beyond the Western cultural context (Hatano \& Sugimura, 2017; Skhirtladze et al., 2016; Sugimura \& Mizokami, 2018). The new personal identity models are focused on how identity is formed (process-oriented models, identity styles), on the content of identity (narrative identity), or on both (for example, examining various identity domains in the process-oriented paradigm) or on discovering one's identity by examination of one's own potential (i.e. eudaimonic identity). A comparison of the most frequently examined contemporary perspectives is presented in Table 8. 
Table 8. Contemporary Perspectives on Personal Identity Formation

\begin{tabular}{|c|c|c|}
\hline Theory & Key notions & Method \\
\hline Marcia's Identity Status Paradigm & $\begin{array}{l}\text { Two processes: } \\
\text { commitment, exploration } \\
\text { Four statuses: } \\
\text { achievement, foreclosure, moratorium, diffusion }\end{array}$ & $\begin{array}{l}\text { Ego Identity Incomplete Sentences Blank } \\
\text { (EI-ISB; see: Kroger and Marcia, 2011) } \\
\text { Identity Status Interview } \\
\text { (ISI; Marcia, 1966) } \\
\text { Extended Objective Measure of Ego Identity } \\
\text { Status II } \\
\text { (EOM-EIS-II; Marcia, 1993) }\end{array}$ \\
\hline Crocetti et al.'s Three Factor Model & $\begin{array}{l}\text { Three processes: } \\
\text { commitment, in-depth exploration, reconsider- } \\
\text { ation of commitment } \\
\text { Two cycles: } \\
\text { identity formation, identity maintenance } \\
\text { Five statuses: } \\
\text { achievement, early closure, moratorium, } \\
\text { searching moratorium, diffusion }\end{array}$ & $\begin{array}{l}\text { Utrecht Management of Identity Commit- } \\
\text { ment Scale } \\
\text { (U-MICS; Crocetti, Rubini, Luyckx, et al., } \\
\text { 2008) }\end{array}$ \\
\hline $\begin{array}{l}\text { Luyckx et al.'s Five Dimensional } \\
\text { Model }\end{array}$ & $\begin{array}{l}\text { Five processes: } \\
\text { commitment making, identification with com- } \\
\text { mitment, exploration in breadth, exploration in } \\
\text { depth, ruminative exploration } \\
\text { Two cycles: } \\
\text { identity formation, identity evaluation } \\
\text { Five statuses: } \\
\text { achievement, moratorium, foreclosure, diffused } \\
\text { diffusion, carefree diffusion }\end{array}$ & $\begin{array}{l}\text { Dimensions of Identity Development Scale } \\
\text { (DIDS; Luyckx et al., 2008) }\end{array}$ \\
\hline Berzonsky's Social-Cognitive Model & $\begin{array}{l}\text { Three identity styles: } \\
\text { informational, normative, diffuse avoidant }\end{array}$ & $\begin{array}{l}\text { Identity Styles Inventory } \\
\text { (ISI-5; Berzonsky et al., 2013) }\end{array}$ \\
\hline $\begin{array}{l}\text { Cieciuch and Topolewska's Identity } \\
\text { Circumplex Model }\end{array}$ & $\begin{array}{l}\text { Eight modes of identity formation: } \\
\text { socialization, consolidation, exploration, } \\
\text { moratorivity, defiance, diffusion, petrification, } \\
\text { normativity }\end{array}$ & $\begin{array}{l}\text { Circumplex Identity Modes Questionnaire } \\
\text { (CIMQ, Topolewska \& Cieciuch, 2017) }\end{array}$ \\
\hline $\begin{array}{l}\text { Whitbourne's Identity Processing } \\
\text { Theory }\end{array}$ & $\begin{array}{l}\text { Identity in adulthood } \\
\text { Three processes: } \\
\text { assimilation, accommodation, balance }\end{array}$ & $\begin{array}{l}\text { Identity and Experiences Scale } \\
\text { (IES; Whitbourne, Sneed, \& Skultety, 2002) }\end{array}$ \\
\hline McAdams' Narrative Identity & $\begin{array}{l}\text { Identity as a life story } \\
\text { Three levels of individuality: } \\
\text { traits, personal characteristics, evolving life } \\
\text { stories }\end{array}$ & $\begin{array}{l}\text { Life Story Interview } \\
\text { (McAdams, 1993) }\end{array}$ \\
\hline Waterman's Eudaimonic Identity & $\begin{array}{l}\text { Eudaimonia } \\
\text { Personal expressiveness } \\
+ \text { commitment and exploration }\end{array}$ & $\begin{array}{l}\text { Dimensions of Identity Development Scale } \\
\text { (DIDS; Luyckx et al., 2008) } \\
\text { Questionnaire for Eudaimonic Well-Being } \\
\text { (QEWB; Waterman et al., 2010) }\end{array}$ \\
\hline
\end{tabular}

Identity can be studied using pen-and-paper methods, narrative interviews, or mixed methods. There are thousands of articles (for a review see: Schwartz, Luyckx, \& Crocetti, 2015) examining identity. The most frequently examined identity correlates are family relationships, personality, various aspects of well-being, internalizing and externalizing symptoms, and problematic behaviours (Schwartz et al, 2015).

The need to make connections and provide a theoretical integration between the variety of theoretical approaches has been noted some time ago (Schwartz, 2001). Some efforts have been made, for example by linking identity commitment to the eudaimonic perspective 
(Waterman \& Schwartz, 2013); by proposing the notion of identity consolidation, defined as developing identity capital, through making commitments and experiencing oneself as a valuable member of society (Schwartz, 2007); or by linking identity styles with statuses (Crocetti et al., 2013; Negru-Subtirica, Pop, \& Crocetti, 2017), and the structural analyses of the five dimensional models to derive an additional dimension - reconsideration of commitment (Zimmermann, Lannegrand-Willems, Safont-Mottay, \& Cannard, 2015).

However, these attempts link fragments of existing theories or methods, but they do not capture "the wholeness" of identity. Each of the presented models focuses on a slightly different aspect of identity formation. However, it is possible to find similarities between them: for example, both the Crocetti and colleagues'(2008) and the Luyckx and colleagues' (2008) models have in-depth type of exploration, Whitbourne's (1996) accommodation and assimilation are similar to Marcia's (1966) exploration and commitment, and Berzonsky's (1989) normative identity processing style is similar to Marcia's (1996) foreclosure status. Still, there are many co-existing models in the literature but few attempts to integrate these existing models. One of the few attempts at integration has been made by Cieciuch and Topolewska (2017), who proposed the Circumplex Model of Identity Formation Modes by combining existing knowledge and various theoretical models from the Marcia approach. The main aim of the CIFM model is to establish a framework under which identity-related constructs could be gathered together and the relations between them could be organized and presented systematically.

Marcia's (1966) identity model and the models derived from it have been validated in Europe (including post-communist countries; Negru-Subtirica \& Damian, 2018; Skhirtladze et al., 2016), the United States, as well as in some non-Western cultures, such as Far East and African Countries (see: Kroger, 2015), and Japan which is characterized by the elements of both collectivism and individualism (Hatano \& Sugimura, 2017; Sugimura \& Mizokami, 2018). An extended review of identity research conducted in Marcia's tradition was presented by Schwartz (2011, 2017). However, it is important to note that cultural aspects are a strong factor in influencing the level and the dynamics of identity processes (see: Hatano \& Sugimura, 2017; Negru-Subtirica, \& Pop, 2018). These cultural influences on identity processes may be due to the differences in socio-economic systems, parental attitudes, the values promoted in educational system (Negru-Subtirica \& Damian, 2018) or the differences between individualistic and collective cultures (Hofstede, 2001).

One important factor related to possible differences in identity development between Western and non-Western cultures may be values, which can be treated as an important element of identity content (Berzonsky, Cieciuch, Duriez, \& Soenens, 2010). For instance, in different societies have different value preferences (e.g., family values versus individualistic values). These value preferences can have a strong impact on future educational and vocational decisions and further development (Negru-Subtirica \& Damian, 2018). However, differences are not limited to those found between Western and non-Western contexts. For example, in Europe there are dissimilarities in identity dimensions between countries from either side of the Iron Curtain (Negru-Subtirica \& Damian, 2018; Shkirtladze et al., 2016). These differences may be the result of factors such as socio-economic and historical contexts impacting the educational choices of young people or leading to valuing different life achievements, which can influence identity commitments.

Thus, when examining identity, one should always consider the context (such as socio-economical or cultural) and the specifics of sample population. In the future, more effort should be put into integrating existing perspectives, rather than into proposing completely new models. Researchers should strive to examine the various identity contexts/ domains, while taking cultural contexts into account, to use mixed-methods research and to capture the developmental processes underlying identity formation. 


\section{A C K N O W LED GEMENTS}

This research was undertaken with the partial financial support by the Erasmus+ Programme of the European Union, strategic partnership project "Innovative Curriculum for Strong Identities in Diverse Europe (INSIDE)" No. 2016-1-LTO1-KA203-023220.

\section{REFERENCES}

Arnett, J. J. (2000). Emerging adulthood: A theory of development from the late teens through the twenties. American Psychologist, 55(5), 469-480.

Berzonsky, M. D. (1989). Identity style: conceptualization and measurement. Journal of Adolescent Research, 4, 268-282.

Berzonsky M. D. (2003), Identity style and well-being: does commitment matter? Identity: an International Journal of Theory and Research, 3(2), $131-142$.

Berzonsky, M. D. (2004). Identity processing style, self-construction, and personal epistemic assumptions: A social-cognitive perspective. European Journal of Developmental Psychology, 1(4), 303-315.

Berzonsky, M. D. (2010). A Social-Cognitive Perspective on Identity Construction. In S. J. Schwartz, K. Luyckx \& V. Vignoles (Eds.), Handbook of identity theory and research (pp. 55-76). New York: Springer.

Berzonsky, M. D., Cieciuch, J., Duriez, B., \& Soenens, B. (2011). The how and what of identity formation: Associations between identity styles and value orientations. Personality and Individual Differences, 50(2), 295-299.

Berzonsky, M. D., Soenens, B., Luyckx, K., Smits, I., Papini, D. R., \& Goossens, L. (2013). Development and Validation of the Revised Identity Style Inventory (ISI-5): Factor Structure, Reliability, and Validity. Psychological Assessment, 25(3), 893-904.

Bosma, H. A. (1992). Identity in adolescence: Managing commitments. In G.R. Adams, T.P. Gullotta, \& R. Montemayor, (Eds.) Identity Formation and Development Advances in Adolescent Development, Volume 4 (pp. 91-121). Newbury Park: Sage Publications.

Bosma, H. A. \& Kunnen, S. E. (2001). Determinants and mechanisms in ego identity development: a review and synthesis. Developmental Review, 21, 39-66.

Cieciuch, J. (2010). Struktura czynnikowa Kwestionariusza Stylów Tożsamości Michaela D. Berzonsky'ego. Ile stylów mierzy ISI3? [The factor structure of Michael Berzonsky's Identity Style Inventory. How many styles does ISI-3 measure?] Psychologia Rozwojowa [Developmental Psychology], 15(4), 49-64.

Cieciuch, J. \& Topolewska, E. (2017). Circumplex of identity formation modes: A proposal for the integration of identity constructs developed in the Erikson-Marcia tradition. Self and Identity, 16(1), 37-61.

COBUILD Advanced American English Dictionary (2016). Glasgow: HarperCollins Publishers.

Colman, A.M. (2003). Oxford Dictionary of Psychology. Oxford University Press.

Crocetti, E. (2017) Identity Formation in Adolescence: The Dynamic of Forming and Consolidating Identity Commitments. Child Development Perspectives 11(2), $145-150$.

Crocetti, E., Branje, S., Rubini, M., Koot, H. M., \& Meeus, W. (2017). Identity processes and parent-child and sibling relationships in adolescence: A five-wave multi-informant longitudinal study. Child Development, 88, 210-228.

Crocetti E., Cieciuch, J., Gao, C.-H., Klimstra, T., Lin, C.-L., Matos, P. M., Morsünbül, Ü., Negru, 0., Sugimura, K., Zimmermann, G., \& Meeus, W. (2015). National and gender measurement invariance of the Utrecht-Management of Identity Commitments Scale (U-MICS): A ten-nation cross-cultural study. Assessment, 22(6), 753-768.

Crocetti, E., Klimstra, T. A., Hale, W. W. III, Koot, H. M., \& Meeus, W. (2013). Impact of early adolescent externalizing problem behaviors on identity development in middle to late adolescence: A prospective 7-year longitudinal study. Journal of Youth and Adolescence, 42, 1745-1758.

Crocetti, E., Klimstra, T., Keijsers, L., Hale, W. W. III, \& Meeus, W. (2009). Anxiety trajectories and identity development in adolescence: A five-wave longitudinal study. Journal of Youth and Adolescence, 38, 839-849.

Crocetti, E., Rubini, M., Luyckx, K., \& Meeus, W. (2008). Identity formation in early and middle adolescents from various ethnic groups: From three dimensions to five statuses. Journal of Adolescence, 37, 983-996.

Crocetti, E., Rubini, M., \& Meeus, W. (2008). Capturing the dynamics of identity formation in various ethnic groups: Development and validation of three-dimensional model. Journal of Adolescence, 31, 207-222.

Crocetti, E., Sica, L. S., Schwartz, S. J., Serafini, T., \& Meeus, W. (2013). Identity styles, processes, statuses, and functions: Making connections among identity dimensions. European Review of Applied Psychology, 63, 1-13.

Crocetti, E., Schwartz, S. J., Fermani, A., \& Meeus, W. (2010). The Utrecht-Management of Identity Commitments Scale (U-MICS): Italian validation and cross-national comparisons. European Journal of Psychological Assessment, 26, 172-186.

Dimitrova, R., Crocetti, E., Buzea, C., Jordanov, V., Kosic, M., Tair, E., Taušová, J., van Cittert, N., \& Uka, F. (2015) , February 27). The Utrecht-Management of Identity Commitments Scale(U-MICS): Measurement Invariance and Cross-National Comparisons of Youth From Seven European Countries. European Journal of Psychological Assessment, 32(2), 119-127.

Dollinger, S. J. \& Clancy Dollinger, S. M. (1997). Individuality and Identity Exploration: An Autophotographic Study. Journal of Research in Personality, 31(31), 337354.

Duriez, B., Soenens, B., \& Beyers, W. (2004). Personality, identity styles, and religiosity: An integrative study among late adolescents in Flanders (Belgium). Journal of Personality, 72(5), 877-910. 
Drever, J. (1947). The Penguin Dictionary of Psychology, New Delhi: Penguin Books.

EBSCO Information Services (retrieved 2018, April, 6th). https://www.ebsco.com/

Erikson E. H. (1950). Childhood and society. Norton, New York.

Erikson E. H. (1968). Identity: Youth and crisis. Norton, New York.

Erikson, E.H. (1980). Identity and the life cycle: selected papers. New York: Norton.

Grotevant, H. D. (1987). Toward a process model of identity formation. Journal of Adolescent Research, 2, 203-222.

Hatano, K., Sugimura, K. (2017). Is adolescence a period of identity formation for all youth? Insights from a four-wave longitudinal study of identity dynamics in Japan. Developmental Psychology, 53(11), 2113-2126.

Hatano, K., Sugimura, K., \& Klimstra, T. A. (2016). Which came first, personality traits or identity processes during early and middle adolescence? Journal of Research in Personality, 67, 120-131. doi:10.1016/j. jrp.2016.06.014

Havighurst, R. J. (1948). Developmental tasks and education. Chicago: University of Chicago Press.

Hofstede, G. (2001). Culture's consequences: Comparing values, behaviors, institutions, and organizations across nations. Thousand Oaks, CA: Sage.

Karaś, D., \& Cieciuch, J. (2015). A domain-focused approach to identity formation. Verification of the three-dimensional model in various life domains in emerging adults. Psychological Studies, 53(3), 63-75.

Karaś, D., Cieciuch, J., Negru, 0., \& Crocetti, E. (2015). relationships between identity and well-being in Italian, Polish, and Romanian emerging adults. Social Indicators Research, 121(3), 727-109.

Klimstra, T. A., Luyckx, K., Goossens, L., Teppers, E., \& De Fruyt, F. (2013). Associations of identity dimensions with big five personality domains and facets. European Journal of Personality, 27, 213-221. doi:10.1002/per.1853

Kroger, J. (2015). Identity development trough adulthood: the move toward "wholeness". In K. C. McLean \& M. Syed (Eds.), Oxford library of psychology. The Oxford handbook of identity development (pp. 65-80). New York: Oxford University Press.

Kroger, J. \& Marcia, J. E. (2011). The identity statuses: Origins, meanings, and interpretations. In S. J. Schwartz, K. Luyckx, \& V. L. Vignoles (Eds.), Handbook of identity theory and research (pp. 31-53). New York: Springer.

Llorent, V. J. \& Alamo, M. (2018). Utrecht-Management of Identity Commitments Scale: Validation in Spanish University Students. Frontiers in Psychology, 2018; 9 : 1364 , online publication.

Luyckx, K., Goossens, L., \& Soenens, B. (2006). A developmental contextual perspective on identity construction in emerging adulthood: Change dynamics in commitment formation and commitment evaluation. Developmental Psychology, 42, 366-380.

Luyckx, K., Goossens, L, Soenens, B., \& Beyers, W. (2006). Unpacking commitment and exploration - preliminary validation of an integrative model of late adolescent identity formation. Journal of Adolescence, 29, 361-378.

Luyckx, K., Goossens, L., Soenens, B., Beyers, W., \& Vansteenkiste, M. (2005). Identity statuses based upon four rather than two identity dimensions: Extending and refining Marcia's paradigm. Journal of Youth and Adolescence, 34, 605-618.

Luyckx, K., Schwartz, S. J., Berzonsky, M. D., Soenens, B., Vansteenkiste, M., Smits, I., \& Goossens, L. (2008). Capturing ruminative exploration: Extending the four-dimensional model of identity formation in late adolescence. Journal of Research in Personality, 42, 58-82.

Luyckx, K., Soenens, B., Berzonsky, M. D., Smits, I., Goossens, L., \& Vansteenkiste, M. (2007). Information-oriented identity processing, identity consolidation, and well-being: The moderating role of autonomy, self-reflection, and self-rumination. Personality and Individual Differences, 43(5), $1099-1111$.

Luyckx, K., Soenens, B., Goossens, L., Beckx, K., \& Wouters, S., (2008). Identity exploration and commitment in late adolescence: correlates of perfectionism and mediating mechanisms on the pathway to well-being. Journal of Social and Clinical Psychology, 27(4), 336-361.

Mannerström, R., Hautamäki, A., \& Leikas, S. (2016) Identity status among young adults: Validation of the Dimensions of Identity Development Scale (DIDS) in a Finnish sample. Nordic Psychology, 69(3), 1-19.

Marcia, J.E. (1966). Development and validation of ego-identity status. Journal of Personality and Social Psychology, 3(5), 551-558.

Marcia, J. E. (1980). Identity in adolescence. In J. Adelson (Ed.), Handbook of adolescent psychology, pp. 109-137. New York: Wiley.

Marcia, J. E. (1993), The ego identity status approach to ego identity. In D. R. Matteson, J. L. Orlofsky, A. S. Waterman, S. L, Archer, \& J. E. Marcia (Eds.), Ego identity: A handhook of psychosocial research (pp. 3-21). New York: Springer.

Mastrotheodoros, S. \& Motti, F. (2016). Dimensions of Identity Development Scale (DIDS): A test of longitudinal measurement invariance in Greek adolescents. European Journal of Developmental Psychology, 14(5), 1-13.

Matsumoto, D. (2009). The Cambridge Dictionary of Psychology. New York: Cambridge University Press.

McAdams, D. P. (1985). Power, intimacy, and the life story: Personological inquiries into identity. New York: Guilford Press.

McAdams, D. P. (1993). The stories we live by: Personal myths and the making of the self. New York: William Morrow.

McAdams, D. P. (1995). What Do We Know When We Know a Person? Journal of Personality 6(3), 365-396.

McAdams, D. P. (2011). Narrative identity. In Schwartz, S. J., Luyckx, K., \& Vignoles, V. L. (Eds.), Handbook of identity theory and research (pp. 99-115). New York: Springer.

McAdams, D. P., Anyidoho, N. A., Brown, C., Huang, Y. T., Kaplan, B., \& Machado, M. A. (2004). Traits and stories: Links between dispositional and narrative features of personality. Journal of Personality, 72, 761-784.

McAdams, D. P. \& McLean, K. C. (2013). Narrative Identity. Current Directions in Psychological Science, 22, 233-238.

Meeus, W. (1996). Studies on identity development in adolescence: An overview of research and some new data. Journal of Youth and Adolescence, 25(5), 569-598.

Meeus, W., ledema, J., \& Maassen, G. H. (2002). Commitment and exploration as mechanisms of identity formation. Psychological Reports, 90, 771-785.

Morsunbul, U. \& Cok, F. (2014). The adaptation of the dimensions of identity development scale into Turkish. The Journal of Psychiatry and Neurological Sciences, 27, 6-14.

Nakama, R., Sugimura, K., Hatano, K., Mizokami, S., \&Tsuzuki, M. (2015). Researching identity development and statuses with the Dimensions of Identity Development Scale: the Japanese version. The Japanese Journal of Psychology, 85(6), 549-559. 
Negru-Subtirica, 0., Pop, E. I., \& Crocetti, E. (2017). A longitudinal integration of identity styles and educational identity processes in adolescence. Developmental Psychology, 53, 2127-2138.

Negru-Subtirica, 0. \& Damian, L. E. (2018). The great escape: Linking youth identity development to growing up in post-communist Romania. In: Lebedeva N., Dimitrova R., \& Berry J. (Eds), Changing values and identities in the post-communist world. Societies and political orders in transition (pp. 333-347). Springer International Publishing, Cham: Switzerland.

Pals Lilgendahl, J. (2015). The dynamic role of identity processes in personality development: Theories, patterns, and new directions. In K. C. McLean \& M. Syed (Eds.), The Oxford Handbook of Identity Development (pp. 490-507). Oxford: Oxford University Press.

Reber, A. S., Allen, R., \& Reber, E. S. (2009). The Penguin Dictionary of Psychology (4th Edition). London: Penguin Books.

Schwartz, S. J. (2001). The evolution of Eriksonian and neo-Eriksonian identity theory and research: A review and integration. Identity: An International Journal of Theory and Research, 1,7-58.

Schwartz, S. J. (2007). The structure of identity consolidation: Multiple correlated constructs or one superordinate construct? Identity: An International Journal of Theory and Research, 7, 27-49.

Schwartz, S. J., Adamson, L., Ferrer-Wreder, L., Dillon, F. R., \& Berman, S. L. (2006).Identity Status Measurement Across Contexts: Variations in Measurement Structure and Mean Levels Among White American, Hispanic American, and Swedish Emerging Adults. Journal of Personality Assessment, 86(1), 61-76.

Schwartz, S. J., Luyckx, K., \& Crocetti, E. (2015). What have we learned since Schwartz (2001)?: A reappraisal of the field of identity development. In K. C. McLean \& M. Syed (Eds.), Oxford library of psychology. The Oxford handbook of identity development (pp. 539-561). New York: Oxford University Press.

Schwartz, S. J., Zamboanga, B. L., Weisskirch, R. S., \& Rodriguez, L. (2009). The relationships of personal and ethnic identity exploration to indices of adaptive and maladaptive psychosocial functioning. International Journal of Behavioral Development, 33, 131-144.

Skhirtladze, N., Javakhishvili, N., Schwartz, S. J., Beyers, W., \& Luyckx, K. (2016). Identity processes and statuses in post-Soviet Georgia: Exploration processes operate differently. Journal of Adolescence, 47, 197-209.

Soenens, B., Luyckx, K., Vansteenkiste, M., \& Goossens, L. (2008). Clarifying the link between parental psychological control and adolescents' depressive feelings: A test of reciprocal versus unidirectional models of influence. Merrill-Palmer Quarterly, 54, 411-444.

Stephen, J., Fraser, E., \& Marcia, J.E. (1992). Moratorium-achievement (Mama) cycles in lifespan identity development: Value orientations and reasoning system correlates. Journal of Adolescence, 15, 283-300.

Sugimura, K. \& Mizokami, S. (2012). Personal identity in Japan. New Directions for Child and Adolescent Development, 138, 123-143

Sugimura, K., Niwa, T., Takahashi, A., Sugiura, Y., Jinno, M., \& Crocetti, E. (2015). Cultural self-construction and identity formation in emerging adulthood: A study on Japanese university students and workers. Journal of Youth Studies, 18, 1326-1346.

Topolewska, E. \& Cieciuch, J. (2015). Internal differentiation of the diffuse-avoidant style in Berzonsky's model: The results of analyses in variable-centered approaches. Studia Psychologiczne, 53(3), 75-86.

Topolewska, E. \& Cieciuch, J. (2017). Empirical verification of the circumplex of identity formation modes and its potential to integrate different models of identity development in the Erikson-Marcia tradition. Self and Identity, 16(2), 123-142.

Topolewska-Siedzik, E., Cieciuch, J., \& Strus, W. (2018). Personality underpinnings of identity: The role of metatraits and traits in identity formation modes. Self and Identity. DOI: 10.1080/15298868.2018.1483964

Topolewska-Siedzik, E. \& Cieciuch, J. (2018). Trajectories of Identity Formation Modes and Their Personality Context in Adolescence. Journal of Youth and Adolescence. DOI: $10.1007 /$ s10964-018-0824-7

VandenBos, G. R. (2007). APA Dictionary of Psychology. Washington: American Psychologcal Association.

Vignoles, V.L., Schwartz, S.J., \& Luyckx, K. (2011) Introduction: Toward an Integrative View of Identity. In S. J. Schwartz, K. Luyckx, V. L. Vignoles, Eds. Handbook of Identity Theory and Research, vol. 1 Structures and Processes (pp. 1-27). New York: Springer.

Vleioras, G. \& Bosma, H. A. (2005). Are identity styles important for psychological well-being? Journal of Adolescence, 28(3), 397-409.

Waterman, A. S. (1982). Identity development from adolescence to adulthood: An extension of theory and a review of research. Developmental Psychology, $342-358$.

Waterman, A. S. (1993). Two conceptions of happiness: Contrasts of personal expressiveness (eudaimonia) and hedonic enjoyment. Journal of Personality and Social Psychology, 64, 678-691.

Waterman, A.S. (2011). Eudaimonic Identity Theory: Identity as Self-Discovery. In Seth J. Schwartz, Koen Luyckx \& Vivian L. Vignoles (Eds.), Handbook of Identity Theory and Research vol. 1 Structures and Processes (pp. 357-379). New York: Springer.

Waterman, A. S. \& Schwartz, S. J. (2013). Eudaimonic identity theory. In A. S. Waterman (Ed.), The best within us: Positive psychology perspectives on eudaimonia (pp. 99-118). Washington, DC: American Psychological Association.

Waterman, A. S., Schwartz, S. J., Hardy, S. A., Kim, S. Y., Lee, R. M., Armenta, B. A., Whitbourne, S. K., Zamboanga, B. L., Brown, E. J., Williams, M. K., \& Agocha, V. B. (2013). Good Choices, poor Choices: Relationship Between the Quality of Identity Commitments and Psychosocial Functioning. Emerging Adulthood, 1(3), 163-174.

Whitbourne, S. K. (1996). Psychosocial perspectives on emotions: The role of identity in the aging process. In C. Magai \& S. McFadden (Eds.), Handbook of emotion, adult development, and aging (pp. 83-98). San Diego: Academic Press.

Whitbourne, S. K. \& Collins, K. C. (1998). Identity and physical changes in later adulthood: Theoretical and clinical implications. Psychotherapy, 35, 519-530.

Whitbourne, S. K. \& Connelly, L. A. (1999). The developing self in midlife. In S. L. Willis \& J. D. Reid (Eds.), Life in the middle: Psychological and social development in middle age (pp. 25-45). San Diego: Academic Press.

Whitbourne, S., Sneed, J. R., \& Skultety, K.M. (2002). Identity processes in adulthood: Theoretical and methodological challenges. Identity: An International Journal of Theory and Research, 2, 29-45.

Wilt, J., Olson, B. D., \& McAdams, D. P. (2011). Higher-order factors of the Big Five predict exploration and threat in life stories. Journal of Research in Personality, 45, 613-621. https://doi.org/ 10.1016/j.jp.2011.08.010.

Zimmermann, G., Lannegrand-Willems, L., Safont-Mottay, C., \& Cannard, C. (2015). Testing new identity models and processes in French-speaking adolescents and emerging adults students. Journal of Youth and Adolescence, 44(1), 127-141.

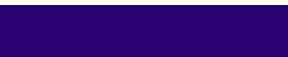

